\title{
Grass grub tolerant pastures and fertiliser nitrogen as an alternative to white clover in pasture subject to grass grub attack
}

D.A. McCallum', N.A. Thomson' and A.H.C. Roberts $^{3}$

'Taranaki Agricultural Research Station, MAFTech, Normanby

'Flock House Agricultural Centre, MAFTech, Bulls

${ }^{3}$ Ruakura Agricultural Research Centre, MAF, Hamilton

ABSTRACT The effect of replacing white clover with fertiliser nitrogen $(\mathrm{N})$ on dry matter production and grass grub populations in 'Grasslands Roa' tell fescue (Festuca arundinacea Schreb.), 'Grasslands Mat-u' phalaris (Phalaris aquatica L.), 'Grasslands Kara' cocksfoot (Dactylis glomerata L.), 'Grasslands Mama' prairie grass (Bromus willdenowii Kunth) and 'old' (30 year plus) ryegrass was measured over a 2 year period. For all pastures the replacement of white clover with fertiliser $\mathrm{N}$ significantly reduced grass grub numbers. This was greatest in tall fescue, phalaris and cocksfoot, showing that pure swards of these species were resistant to grass grub. Decreases in grass grub numbers in ryegrass and prairie grass were less. There was overall a significant increase in pasture production by eliminating white clover and applying fertiliser $\mathrm{N}$, with a differential response between species. Average annual production of prairie grass was unaffected, whereas the yield of cocksfoot increased by $9 \%$ and old ryegrass, phalaris and tall fescue increased by $26 \%$. Most of this extra production for tall fescue and phalaris occurred in autumn. These results show that the use of tall fescue and phalaris and the replacement of white clover with fertiliser $\mathrm{N}$ has potential for increasing pasture production in districts subject to grass damage.

Keywords old ryegrass, Roa tall fescue, Maru phalaris, Kara cocksfoot, Matua prairie grass, white clover, grass grub, nitrogen fertiliser

\section{INTRODUCTION}

Lucerne sown as a grass grub resistant dairy pasture for the Taranaki region was uneconomic (Thomson et al. 198 1). Studies have continued to evaluate grasses that are tolerant to grass grub. Kain et al. (1979) showed that tall fescue, phalaris, cocksfoot and prairie grass had a degree of tolerance to grass grub. Clover, however, is an extremely favourable host plant for grass grub (Kain \& Atkinson 1977) and as tolerant grasses are sown with clovers grass grub damage may still occur. Therefore, tolerant grasses, sown without white clover hut supplemented with nitrogen $(\mathrm{N})$ fertiliser could provide a pasture with high production and high grass grub tolerance for areas prone to grass grub attack.

\section{MATERIALS AND METHODS}

The study was conducted at the Taranaki Agricultural Research Station over a 2-year period from autumn 1985 to autumn 1987. Old ryegrass was compared with 'Grasslands Roa' tall fescue (Festuca arundinacea Schreb.), 'Grasslands Maru' phalaris (Phalaris aquatica L.), 'Grasslands Kara' cocksfoot (Dactylis glomerata L.) and 'Grasslands Matua' prairie grass (Bromus willdenowii Kunth) all sown between 1981 and 1984 in 1 ha paddocks as pure swards with 'Grasslands Pitau' white clover. Within 2 selected paddocks of each grass species, 4 sets of subplots of either white clover or no white clover plus nitrogen were allocated. This gave a $2 \times 5 \times 4$ factorial design. Subplot size was $6 \mathrm{~m} \times 10 \mathrm{~m}$. However, as the location of the 2 paddocks of each species was not entirely random, a statistical comparison between species was invalid.

The clover in $\mathrm{N}$ plots was reduced to a low level by spraying on 3 occasions over the duration of the trial with a mixture of MCPA $(1.75$ 1/ha) and dicamba (2 1/ha). Nitrogen as urea was applied proportionally throughout the year according to pasture growth at an annual rate of $240 \mathrm{~kg} \mathrm{~N} / \mathrm{ha}$ (the annual amount of $\mathrm{N}$ estimated to be fixed in the Taranaki/Manawatu environment (Clark et al. 1979)). In the second year of the trial the $\mathrm{N}$ plots were split and 2 rates of $\mathrm{N}$ were applied (240 and $480 \mathrm{~kg} \mathrm{~N} / \mathrm{ha}$ ), to assess whether $\mathrm{N}$ was a limiting factor and if the grasses had different $\mathrm{N}$ requirements.

Throughout the results section the no white clover plus $\mathrm{N}$ fettiliser treatments will be referred to as fertiliser $\mathrm{N}$ treatments and old ryegrass as ryegrass.

All paddocks were grazed rotationally by dairy cows. Production cuts were taken with a rotary mower (one strip per plot) before grazing the individual paddocks, with a new area trimmed after grazing. Seasonal herbage samples were cut to grazing height with shears immediately before grazing, and dissected into sown grass, legumes, weeds, dead and unsown species. Grass grub populations were monitored in May each year by taking ten $10-\mathrm{cm}$ diameter cores within each subplot. Each core was sorted by hand in the field. 


\section{RESULTS}

\section{Dry matter production}

A highly significant interaction $(\mathrm{P}<0.01)$ occurred between the grasses and cloverlfertiliser $\mathrm{N}$ treatments for annual dry matter production (Table 1). Yields of ryegrass, tall fescue and phalaris were $26 \%$ higher with fertiliser $\mathrm{N}$ than white clover but only $9 \%$ greater for cocksfoot, with no response from prairie grass. Only ryegrass and phalaris responded to the higher $\mathrm{N}$ treatment. The seasonal interaction (Figure 1) showed the following. Over winter all species responded similarly to $\mathrm{N}$ fertiliser. However, cocksfoot did not respond to $\mathrm{N}$ fertiliser in spring and summer and prairie grass in autumn and spring. Differences in production between $\mathrm{N}$ and clover treatments were greatest in autumn.

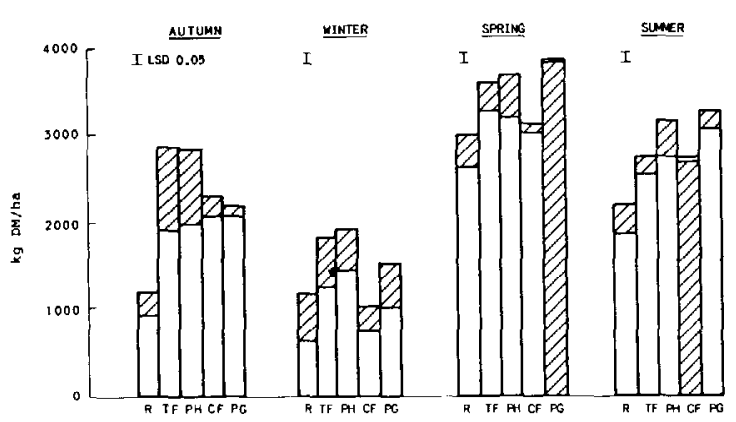

Figure 1 Seasonal yield of 5 grasses grown with white clover (non shaded) or fertiliser $\mathrm{N}$ (shaded) (Average of 2 years). $(\mathrm{R}=$ ryegrass, $\mathrm{TF}=$ tall fescue, $\mathrm{PH}=$ phalaris, $\mathrm{CF}=$ cocksfoot, $\mathrm{PG}=$ prairie grass).

\section{Sown species and clover components}

In the fertiliser $\mathrm{N}$ treatments the sown species component was higher than in the clover treatments and the clover content was reduced to below $3 \%$ (Table 2).

\section{Grass grub populations}

The exclusion of white clover reduced grass grub numbers significantly $(\mathrm{P}<0.05)$ in all species (Figure 2 ), the greatest reduction occurring in tall fescue, phalaris and cocksfoot.

\section{DISCUSSION}

This study confirms that white clover is a highly favourable host for grass grub, populations being higher under grass/clover swards than pure grass swards (Table 2), as reported previously by Kain et al. (1979) and East et al. (1980).

Resistance, as defined by East $\boldsymbol{e t}$ al. (1982), is the ability of a species to suppress grass grub numbers to low levels. Therefore, in this study pure swards of tall fescue, phalaris and cocksfoot were found to be

resistant to grass grub attack. This result for tall fescue is in contract to that of East et al. (1980) who showed tall fescue to be tolerant to grass grub, supporting similar numbers of grass grub to white clover without suffering excessive damage.

The $26 \%$ extra dry matter resulting from the replacement of white clover with fertiliser $\mathrm{N}$ in tall fescue and phalaris could be of possible value in the south Taranaki dairy area, as a large proporiton of this extra growth occurred in autumn (Figure 1) when grass grub feeding is at its peak and feed deficits are common because of low soil moisture levels.

Table 1 Total annual dry matter yield (t/ha) of 5 grasses grown with either white clover or fertiliser $\mathrm{N}$.

\begin{tabular}{|c|c|c|c|}
\hline & & 1985186 & $1986 / 87$ \\
\hline $\begin{array}{l}\text { Established } \\
\text { Ryegrass }\end{array}$ & $\begin{array}{l}\text { Clover } \\
\text { 'Low N } \\
\text { *High N }\end{array}$ & $\begin{array}{c}1.4 \mathrm{a} \mathrm{A} \\
9.1 \mathrm{~b} \mathrm{~B} \\
-\end{array}$ & $\begin{array}{l}4.9 \text { a A } \\
6.3 \mathrm{~b} \mathrm{~B} \\
7.5 \mathrm{c} \mathrm{c}\end{array}$ \\
\hline Tall fescue & $\begin{array}{l}\text { Clover } \\
\text { Low N } \\
\text { High N }\end{array}$ & $\begin{array}{c}10.9 \text { a A } \\
13.8 \text { b B } \\
-\end{array}$ & $\begin{array}{l}6.9 \text { a A } \\
8.7 \text { b B } \\
9.1 \text { b B }\end{array}$ \\
\hline Phalaris & $\begin{array}{l}\text { Clover } \\
\text { Low N } \\
\text { High N }\end{array}$ & $\begin{array}{ccc}12.0 & \text { a } & A \\
13.8 & b & B \\
- & \end{array}$ & $\begin{array}{c}6.9 \text { a A } \\
9.6 \text { b B } \\
10.6 \text { c C }\end{array}$ \\
\hline Cocksfoot & $\begin{array}{l}\text { Clover } \\
\text { Low N } \\
\text { High N }\end{array}$ & $\begin{array}{c}10.2 \text { a A } \\
10.9 \text { b A } \\
-\end{array}$ & $\begin{array}{c}6.7 \mathrm{a} A \\
7.4 \mathrm{~b} A \\
7.7 \mathrm{~b} \mathrm{~A}\end{array}$ \\
\hline Prairie grass & $\begin{array}{l}\text { Clover } \\
\text { Low N } \\
\text { High N }\end{array}$ & $\begin{array}{c}12.7 \text { a A } \\
12.6 \text { A A } \\
-\end{array}$ & $\begin{array}{l}8.4 \text { a } \mathrm{A} \\
8.9 \text { a } \mathrm{A} \\
9.3 \text { a } \mathrm{A}\end{array}$ \\
\hline
\end{tabular}

Within each year and species, treatment means without a common letter are significantly different; lower case $P<0.05$, upper case $\mathrm{P}<0.01$.

Table 2 Average sown species and clover percentages for the 1986/87 season. Treatment means for \% sown and \% clover are significantly different in each species.

\begin{tabular}{|c|c|c|c|c|}
\hline & & $\%$ & Sown $\%$ & Clover \\
\hline \multirow{2}{*}{$\begin{array}{l}\text { Established } \\
\text { ryegrass }\end{array}$} & Clover & & 43 & 12.0 \\
\hline & Fertiliser $\mathrm{N}$ & & 63 & 0.3 \\
\hline \multirow[t]{2}{*}{ Tall fescue } & Clover & & 64 & 16.0 \\
\hline & Fertiliser $\mathrm{N}$ & & 84 & 2.3 \\
\hline \multirow[t]{2}{*}{ Phalaris } & Clover & & 68 & 14.0 \\
\hline & Fertiliser $\mathrm{N}$ & & 88 & 0.4 \\
\hline \multirow[t]{2}{*}{ Cocksfoot } & Clover & & 59 & 18.0 \\
\hline & Fertiliser $\mathrm{N}$ & & 84 & 0.1 \\
\hline \multirow[t]{2}{*}{ Prairie grass } & Clover & & 40 & 22.0 \\
\hline & Fertiliser $\mathrm{N}$ & & 51 & 0.8 \\
\hline
\end{tabular}




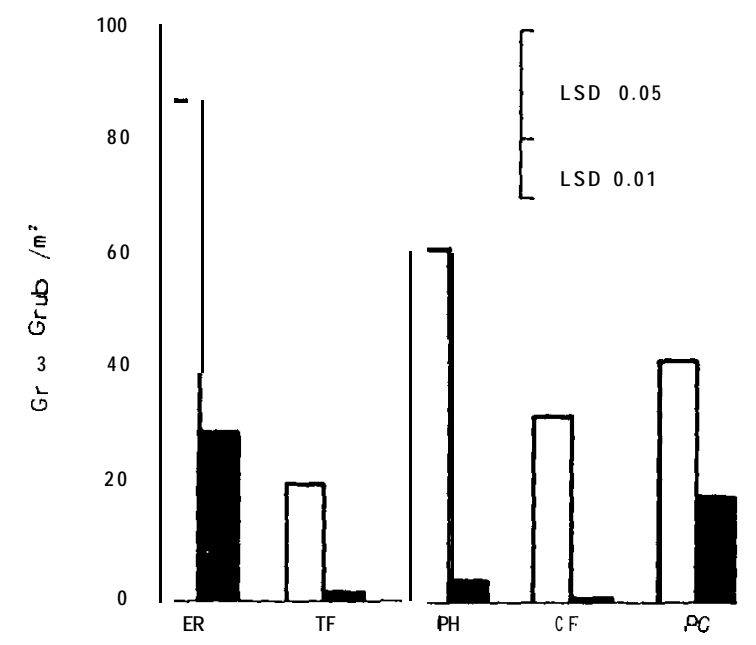

Figure 2 Grass grub populations under 5 grasses with white clover (open bars) and with fertiliser $\mathrm{N}$ (shaded bars) (Average of 2 years).

$(\mathrm{ER}=$ established ryegrass, $\mathrm{TF}=$ tall fescue, $\mathrm{PH}=$ phalaris, $\mathrm{CF}=$ cocksfoot, $\mathrm{PG}=$ prairie grass) .

This result could also have applications for ryegrass pasture. However, as pure ryegrass pastures support a higher grass grub population (Figure 2) and are not drought tolerant, the overall benefit may not be as great as for pure tall fescue and phalaris pastures.

For prairie grass pastures the replacement of clover by $\mathrm{N}$ fertiliser did not reduce grass grub to such low levels as in tall fescue, phalaris and cocksfoot, a result which may be attributed to the low proportion of prairie grass in these pastures $(50-60 \%)$. This, combined with the inability of prairie grass to produce dry matter production as high as in a pure grass sward (Table I), suggests it would not be suitable as a special purpose pasture to combat grass grub attack in the Taranaki region.

\section{CONCLUSION}

The results of this trial have shown that the removal of white clover and the addition of $\mathrm{N}$ fertiliser:

- reduced grass grub populations to low levels in tall fescue, phalaris and cocksfoot.

- increased dry matter production of tall fescue, phalaris and ryegrass.

Therefore the sowing of pure grass swards of tall fescue and phalaris has the potential to maximise production in areas prone to grass grub attack.

As an alternative to insecticide in ryegrass-based pasture, the replacement of white clover with fertiliser $\mathrm{N}$ may be of value.

For these concepts to be fully developed, however, the effect of pure grass swards on animal production, and the cost effectiveness of applying $\mathrm{N}$ fertiliser proportionally throughout the year to large areas, need further study. Also the optimal $\mathrm{N}$ requirements of phalaris and ryegrass need to be determined.

\section{REFERENCES}

Clark D.A.; Causley D.C.; Brougham R.W. 1979. Nitrogen fixation in pasture VI. Manawatu plains, Kairanga. NZ Journal of experimental agriculture 7: 23-25.

East R.; Kain W.M.; Douglas J.A. 1980. The effect of grass grub on the herbage production of different pasture species in the pumice country. Proceedings of the NZ Grassland Association 41: $105-115$.

East R.; Koller M.S.; Willoughby B.E. 1982. Effects of grass grub density on production of tall fescue, cocksfoot and ryegrass sown with white clover. Proceedings of rhe 35th NZ Weed and Pest Conference: 82-85.

Kain W.M.; Atkinson D.S. 1977. Development of resistant pastures and methods of pasture management for grass grub (Costelytra zealandica [white]) control. NZ Journal of agricultural research 212: 501-517.

Kain W.M.; Slay M.W.; Atkinson D.S. 1979. Evaluation of grass grub plant interactions of grasses sown with and without white clover in Central Hawkes Bay. Proceedings of the 32nd Weed and Pest Conference 2: 86-91.

Thomson N.A.; Lagan J.F. 1981. Lucerne not the answer in dairying. NZ Journal of agriculture (May): 13-17. 